\title{
Clinical Value of Neutrophil/Lymphocyte Ratio in Predicting Postoperative Complications and Prognosis in Patients with Colorectal Cancer Undergoing Surgical Treatment
}

\author{
Nötrofil/Lenfosit Oranının Cerrahi Uygulanan Kolorektal Kanserli \\ Hastalarda Postoperatif Komplikasyonları ve Prognozu Öngörebilmedeki \\ Klinik Değeri
}

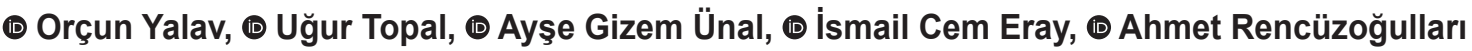 \\ Çukurova University Faculty of Medicine, Department of General Surgery, Adana, Turkey
}

\section{IIIIIIII ABSTRACT}

Aim: Recently, the preoperative systemic inflammatory response has been reported to be a prognostic factor in patients with colorectal cancer (CRC). In this context, the preoperative neutrophil/lymphocyte ratio (NLR) has been proposed as a useful predictor of prognosis. In this study, we aimed to determine the clinical value and prognostic significance of neutrophil/lymphocyte ratio in predicting postoperative complications in patients undergoing surgical treatment for colorectal cancer.

Method: Patients who underwent surgical treatment for colorectal cancer between 2015-2019 were included in the study. group 1 (Low NLR) and group 2 (High NLR) were formed. Demographic and clinical characteristics, intraoperative and postoperative results, and mean survival were compared. The value of NLR in predicting postoperative complications at the determined cut-off value was examined.

Results: Patients were divided into two groups according to the cut-off value of 2.08. Group 1 consisted of 56 patients, and group 2 consisted of 223 patients. Male sex was dominant in both groups (60\% vs 64\%, $\mathrm{p}=0.349)$, while patients in group 2 received more neoadjuvant treatment ( $29.1 \%$ vs $12.5 \%, \mathrm{p}=0.007)$. Intraoperative complication rates were similar $(1.8 \% \mathrm{vs} 4 \%, \mathrm{p}=0.369)$, pathological grade $(\mathrm{p}=0.031)$, and stage $(\mathrm{p}=0.113)$ were similar. Postoperative complications were more common in group 2 ( $24.7 \%$ vs $10.7 \%, \mathrm{p}=0.015)$. Total survival was shorter in group 2 ( 46 months vs. 52 months, $\mathrm{p}=0.025$ ). At the determined cutoff value, NLR predicted postoperative complications with $22.94 \%$ specificity and $90.6 \%$ sensitivity. Conclusion: High NLR was associated with postoperative complications and survival. Although it has a prognostic value, its value in predicting postoperative complications is limited and cannot be used alone.

Keywords: Colorectal cancer, neutrophil/lymphocyte ratio, prognosis

\section{|HIIIII|| ÖZ}

Amaç: Son zamanlarda, preoperatif sistemik enflamatuar yanıtın kolorektal kanserli hastalarda (CRC) prognostik bir faktör olduğu bildirilmiştir. $\mathrm{Bu}$ bağlamda preoperatif nötrofil lenfosit oranı (NLO), prognoz için faydalı bir öngörü faktörü olarak öne sürülmüştür. Bu çalışmada nötrofil/ lenfosit oranının kolorektal kanser nedeniyle cerrahi tedavi uygulanan hastalarda postoperatif komplikasyonları öngörebilmedeki klinik değerini ve prognostik önemini saptamayı amaçladık.

Yöntem: 2015-2019 yılları arasında kolorektal kanser nedeniyle cerrahi tedavi, uygulanan hastalar çalışmaya dahil edili. Grup 1 (NLO düşük) ve grup 2 (NLO yüksek) olmak üzere iki grup oluşturuldu. Gruplarda hastaların demografik ve klinik özellikleri intraoperatif ve postoperatif sonuçlarları ortalama sağkalımları karşılaştırıldı. NLO belirlenen cut off değerinde postoperatif komplikasyonları öngörebilmedeki değerine bakıldı.

Bulgular: Hastalar 2,08 cut-off değerine göre iki gruba ayrıldı grup l=56 hastadan grup 2=223 hastadan oluşuyordu Her iki grupta da erkek cinsiyet baskındı (\%60 vs, \%64 p=0,349), grup 2'deki hastalar daha çok neoadjuvant tedavi almıştı (\%29,1 vs \%12,5 p=0,007), intraoperatif komplikasyon

Address for Correspondence/Yazışma Adresi: Uğur Topal MD,

Çukurova University Faculty of Medicine, Department of General Surgery, Adana, Turkey

Phone: +90 5301139112 E-mail: sutopal2005@hotmail.om

Received/Gelis Tarihi: 24.12.2019 Accepted/Kabul Tarihi: 09.01.2020

${ }^{\oplus}$ Copyright 2020 by Turkish Society of Colon and Rectal Surgery

Turkish Journal of Colorectal Disease published by Galenos Publishing House. 
oranları benzer (\%1,8 vs \%4 p=0,369), Patolojik grade $\mathrm{p}=0,031$ ve evre $\mathrm{p}=0,131$ benzerdi. Postoperatif komplikasyon grup 2'de daha sık görülmüştü (\%24,7 vs \%10,7 p=0,015) Toplam sağ kalım grup2'de daha kısa (46 ay vs 52 ay p=0,025) belirlenen cut-off değerinde NLO \%22,94 spesifite ve \%90,6 sensivite ile hastada postopertif komplikasyonu ön görüyordu.

Sonuç: Yüksek NLO postoperatif komplikasyonlarla ve să̆ kalımla ilişkiliydi. Prognostik değeri olmakla beraber postoperatif komplikasyonları tahmin etmedeki değeri kısıtlıdır ve tek başına kullanılamaz.

Anahtar Kelimeler: Kolorektal kanser, nötrofil/lenfosit oranı, prognoz

\section{Introduction}

Colorectal cancer (CRC) is the third most common type of cancer in men and the second most common type of cancer in women globally, according to the 2012 data of the International Cancer Agency. ${ }^{1}$

It is important to investigate prognostic biological factors in CRC. The patient's outcome may be affected by tumor biology. Similar clinical or pathological characteristics often show different clinical outcomes. Although TNM classification is useful in classifying patients and choosing treatment, patients with the same stage may have different clinical outcomes. Therefore, it is important to detect molecular markers, especially in the selection of adjuvant or targeted therapy, in aggressive CRC.

Inflammation has been shown to play an important role in the pathogenesis and progression of CRC. Lab markers such as C-reactive protein, hypoalbuminemia, Glasgow Prognostic Score, white blood cell count, neutrophil/lymphocyte ratio, or platelet/lymphocyte ratio used to evaluate systemic inflammatory response have been studied as prognostic and predictive factors in various tumoral diseases. ${ }^{2,3,4,5} \mathrm{CRP}$, a marker of systemic inflammation, has been shown to be a prognostic factor in CRC patients. ${ }^{6}$

Neutrophil/lymphocyte ratio (NLR) is calculated by dividing neutrophil count by lymphocyte count in complete blood count and has been suggested to reflect the balance between pro-tumor inflammation and anti-tumor immune function, and its prognostic significance has been studied extensively in many solid tumors. ${ }^{7}$ NLR was reported to be an important prognostic factor in CRC patients. ${ }^{8,9}$

However, inconsistent results also showed that NLR was not an independent prognostic factor for CRC in the Cox regression model of Wei et al. ${ }^{10}$ Therefore, the prognostic value of NLR in CRC is controversial.

The aim of this study was to determine the value of Neutrophil/Lymphocyte Ratio in predicting postoperative complications and prognosis in patients with CRC who underwent curative surgery.

\section{Material and Methods}

After obtaining permission from the Ethics Committee of Çukurova Faculty of Medicine dated 04.09.2019 and numbered 91/29, 344 patients who underwent surgery for colorectal cancer between January 2015 and December 2018 were evaluated retrospectively. Patients who underwent palliative surgery, patients with metastatic disease, patients under the age of eighteen, pregnant patients, patients with chronic or hematological disease, steroid users, and patients whose records could not be reached were excluded from the study. The remaining 279 patients were included in the study.

The patients were divided into two groups according to the cut off value obtained from the ROC curve. Those lower than the cut off value of 2.08 were determined as group 1 (Low NLR), and those higher than 2.08 were determined as group 2 (High NLR). The relationship between NLR and clinicopathological parameters (age, sex, tumor stage, tumor markers, operation details, postoperative complications (clavien dindo 3 and above), wound site infection, intraabdominal abscess, evisceration, postoperative ileus, anastomotic leakage, reoperation, disease-free survival, median follow up) was statistically analyzed.

The criteria for discharge were meal tolerance without nausea or vomiting, defecation or stoma function, adequate pain control by oral analgesia, and independent mobilization.

Blood parameters were measured preoperatively. The total blood count was measured by an automated hematology analyzer (Roche Hitachi Cobas ${ }^{\circledR} 8000$ Roche Diagnostics, Indianapolis, IN, USA). NLR was defined as the absolute neutrophil count divided by the absolute lymphocyte count.

\section{Statistical Analysis}

Data were analyzed using IBM SPSS Statistics for Windows, version 24 (IBM Corp., Armonk, N.Y., USA). In the evaluation of the study data, student's t-test was used for comparison of quantitative data as well as descriptive statistical methods [mean, standard deviation, median, frequency, ratio, minimum (mim), maximum (max)], and Mann-Whitney U test was used for the evaluation of NLR which was not normally distributed. Pearson's chi-square test and Fisher's exact test were used to compare qualitative data, and logistic regression was used for multivariate evaluations. The patients were divided into two groups based on the presence of postoperative complications, 
and receiver operating characteristic (ROC) analysis was performed according to these groups. Diagnostic accuracy was evaluated using ROC curve analysis. Kaplan-Meier and Log Rank tests were used for survival analysis. A p-value of $<0.05$ was considered statistically significant.

\section{Results}

In order to create a cut off value for NLR, ROC analysis and ROC curve were created. As a result of ROC analysis, the area under the ROC curve was calculated as $55.8 \%$. According to the cut off value, if the NLR value is above 2.08 , it is determined that the patient develops postoperative complications with $90.16 \%$ sensitivity and $22.94 \%$ specificity (Shown in Table 1 and Figure 1).

The patients were divided into two groups according to the cut off value of 2.08. Those lower than the cut off value of 2.08 were determined as group 1 (Low NLR), and it consisted of 56 patients, and those higher than 2.08 were determined as group 2 (High NLR) and it consisted of 223. There was no statistically significant difference between the groups in terms of mean age, sex, ASA scores, body mass index and tumor markers $(p>0.05)$. The patients in group 2 received more neoadjuvant treatment (29\% vs $12 \%$, $\mathrm{p}=0.007$ ). Demographic characteristics and preoperative findings of the patients are shown in Table 2.

The rate of laparascopic surgery was similar between the groups $(32.1 \%$ vs $42.6 \% \mathrm{p}=0.101)$. Operation times were similar (168 vs $171 \mathrm{~min}, \mathrm{p}=0.592$ ). Intraoperative

Table 1. Proposed cut-off values for significant parameters in postoperative complications

\begin{tabular}{ll} 
& NLR \\
\hline AUC & 0.558 \\
Cutoff & $>2.08$ \\
Specificity & 22.94 \\
95\%-Cl (\%) & $17.5-29.1$ \\
Sensitive (\%) & 90.16 \\
95\%-Cl (\%) & $79.8-96.3$ \\
PPV & 24.7 \\
NPV & 89.3 \\
+LR & 1.17 \\
-LR & 0.43 \\
p & 0.154 \\
AUC: Area under the curve, CI: Confidence interval, nLLR: Negative \\
likelihood ratio, pLLR: Positive likelihood ratio, NLR: Neutrophil- \\
to-lymphocyte ratio, NPV: Negative predictive value, PPV: Positive \\
predictive value
\end{tabular}

complication rates were also similar ( $1.8 \%$ vs $4 \%, \mathrm{p}=0.369)$. Intraoperative complications were ureteral injury, small bowel injury, and spleen injury. Additional non-tumor intervention rates were similar $(\mathrm{p}=0.446)$. Intraoperative features are given in Table 3.

When we looked at the pathological features of the tumors, histological types were similar $(\mathrm{p}=0.166)$. The rate of poorly differentiated tumors was higher in group 2 than in group $1(21.5 \%$ vs. $8.9 \%, \mathrm{p}=0.031)$. The distribution of the pathological stage was similar $(\mathrm{p}=0.131)$. When we evaluated the response to treatment in patients receiving neoadjuvant treatment, there was no difference between the groups $(p=0.439)$. The pathological characteristics of the tumors are shown in Table 4.

Duration of the postoperativehospitalstaywassimilarbetween the groups $(\mathrm{p}=0.502)$. Postoperative complications were higher in group 2 than group 1 ( $24.7 \%$ vs $10.7 \%, \mathrm{p}=0.015)$. Intraoperative abdominal abscess and postoperative ileus were higher in group $2(\mathrm{p}=0.034 ; \mathrm{p}=0.050$, respectively). Wound infection, anastomotic leakage, and evisceration were similar ( $\mathrm{p}=0.456, \mathrm{p}=0.426$ and $\mathrm{p}=0.574$, respectively). There was no difference between the groups in terms of local recurrence and distant metastasis. Perioperative and postoperative clinical outcomes and oncological outcomes are shown in Table 5.

Total survival was lower in group 2 than in group 1 (46.87 months vs. 52.75 months, $\mathrm{p}=0.025$ ). It is shown in Table 6 and Figure 2. Disease-free survival rates were similar in the groups ( 52.73 vs. 48.13 months, $\mathrm{p}=0.073$ ). It is shown in Table 7 and Figure 3. Median follow up was 29.1 1 13 (1-54) months.

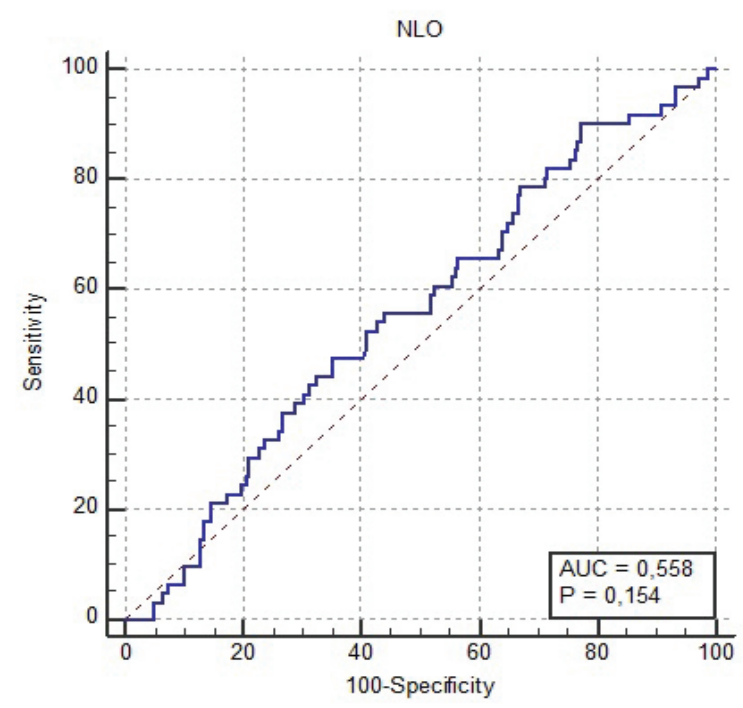

Figure 1. Receiver operating characteristic (ROC) curve analyses for postoperatif complications 
Table 2. Demographic characteristics and preoperative findings of the patients

\begin{tabular}{|c|c|c|c|c|}
\hline & & $\begin{array}{l}\text { Low NLR } \\
\mathrm{n}=56\end{array}$ & $\begin{array}{l}\text { High NLR } \\
\mathrm{n}=223\end{array}$ & $\mathrm{p}^{*}$ \\
\hline \multicolumn{2}{|c|}{ Age (Mean+SD) (Min-max) } & $\begin{array}{l}59.60+11.71 \\
29.0-83.0\end{array}$ & $\begin{array}{l}61.91+12.21 \\
20.0-107.0\end{array}$ & 0.205 \\
\hline Sex & $\begin{array}{l}\text { Male } \\
\text { Female }\end{array}$ & $\begin{array}{l}33(60.0) \\
23(40.0)\end{array}$ & $\begin{array}{l}145(64.7) \\
79(35.3)\end{array}$ & 0.349 \\
\hline ASA Score & $\begin{array}{l}1 \\
2 \\
3\end{array}$ & $\begin{array}{l}24(42.9) \\
21(37.5) \\
11(19.6)\end{array}$ & $\begin{array}{l}111(49.8) \\
71(31.8) \\
41(18.4)\end{array}$ & 0.633 \\
\hline \multicolumn{2}{|c|}{ BMI (Mean+SD) (Min-max) } & $\begin{array}{l}27.17+5.66 \\
19.8-50.0\end{array}$ & $\begin{array}{l}26.13+4.30 \\
18.0-51.0\end{array}$ & 0.131 \\
\hline \multicolumn{2}{|c|}{ CEA (Mean+SD) (Min-max) } & $\begin{array}{l}6.46+14.63 \\
0.0-77.0\end{array}$ & $\begin{array}{l}5.54+12.28 \\
0.0-146.0\end{array}$ & 0.631 \\
\hline \multicolumn{2}{|c|}{ Ca19.9 (Mean+SD) (Min-max) } & $\begin{array}{l}93.59+539.03 \\
0.0-4036.0\end{array}$ & $\begin{array}{l}33.75+137.17 \\
0.0-1760.0\end{array}$ & 0.139 \\
\hline Synchronic & & $8(14.3)$ & $31(13.9)$ & 0.544 \\
\hline Neoadjuvar & & $7(12.5)$ & $65(29.1)$ & 0.007 \\
\hline
\end{tabular}

ASA: American Society of Anaesthesiologists, BMI: Body mass index, CEA: Carcinoembryonic antigen; CRT: Chemoradiotherapy, NLR: Neutrophil/ lymphocyte ratio

Table 3. Intraoperative features

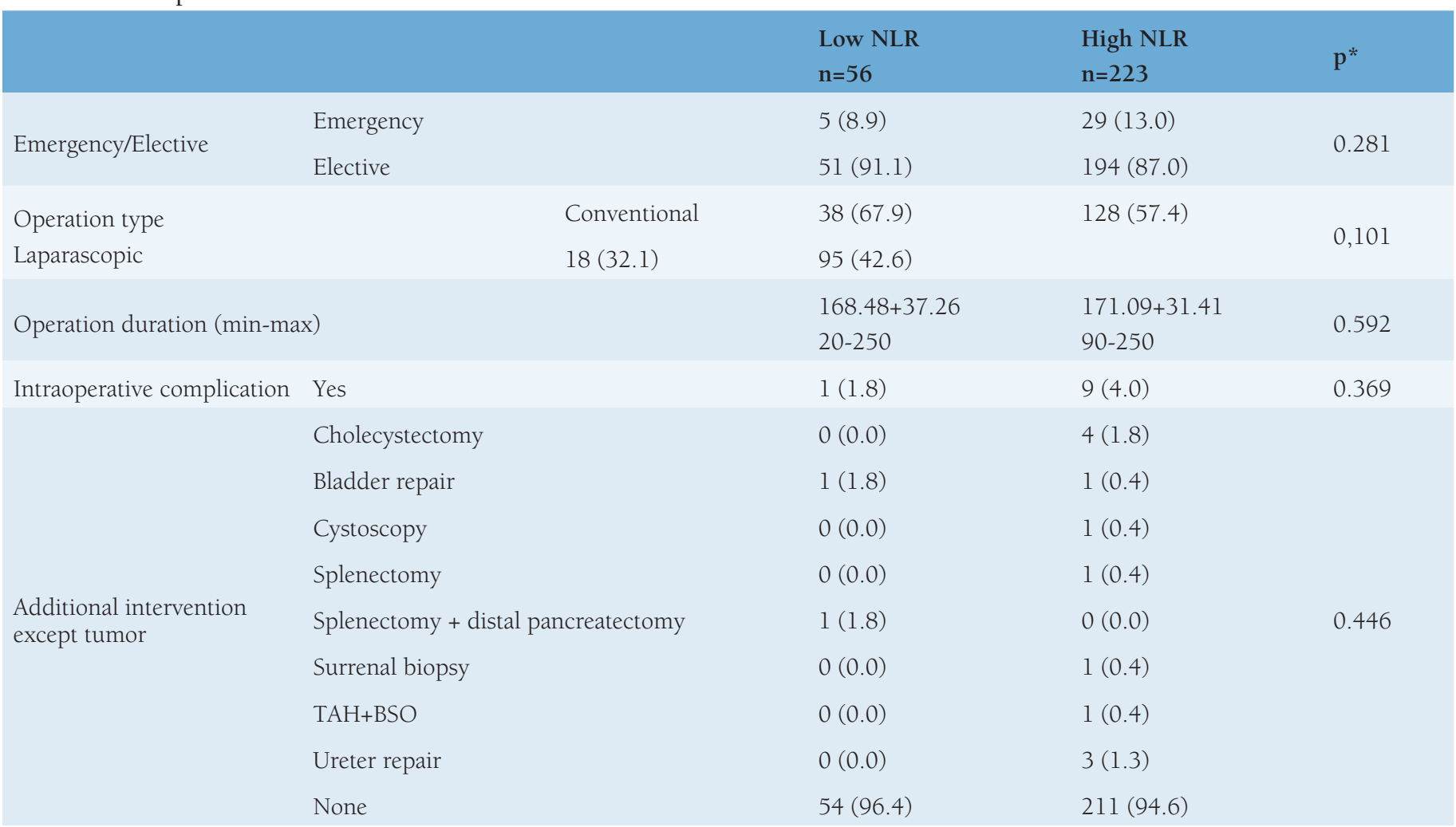

TAH-BSO: Total abdominal hysterectomy + bilateral salpingooopherectomy, min: Minimum, max: Maximum, NLR: Neutrophil/lymphocyte ratio. 
Table 4. Pathological characteristics

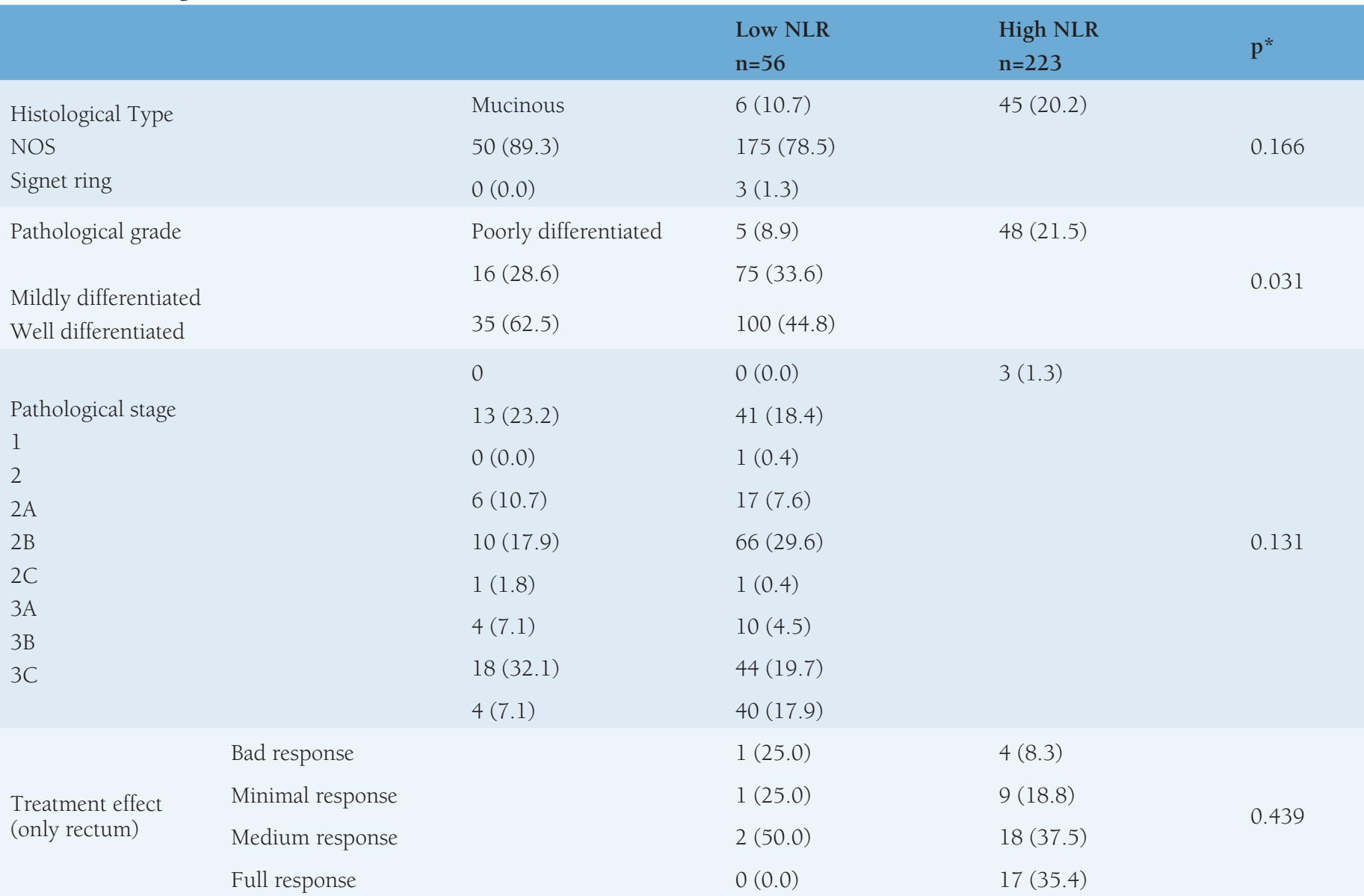

NOS: Not otherwise specified, NLR: Neutrophil/lymphocyte ratio

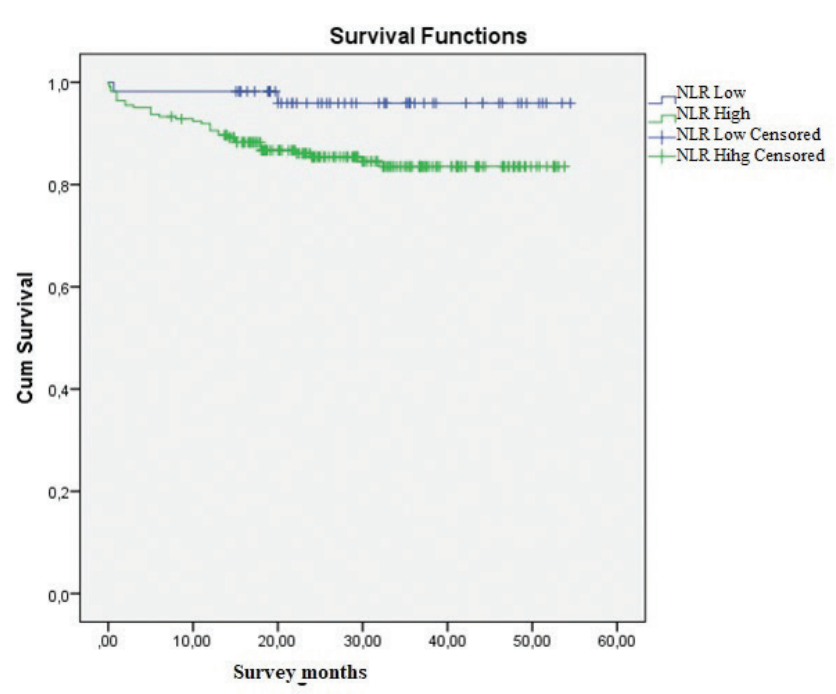

Figure 2. Total survival according to NLR groups NLR: Neutrophil/lymphocyte ratio

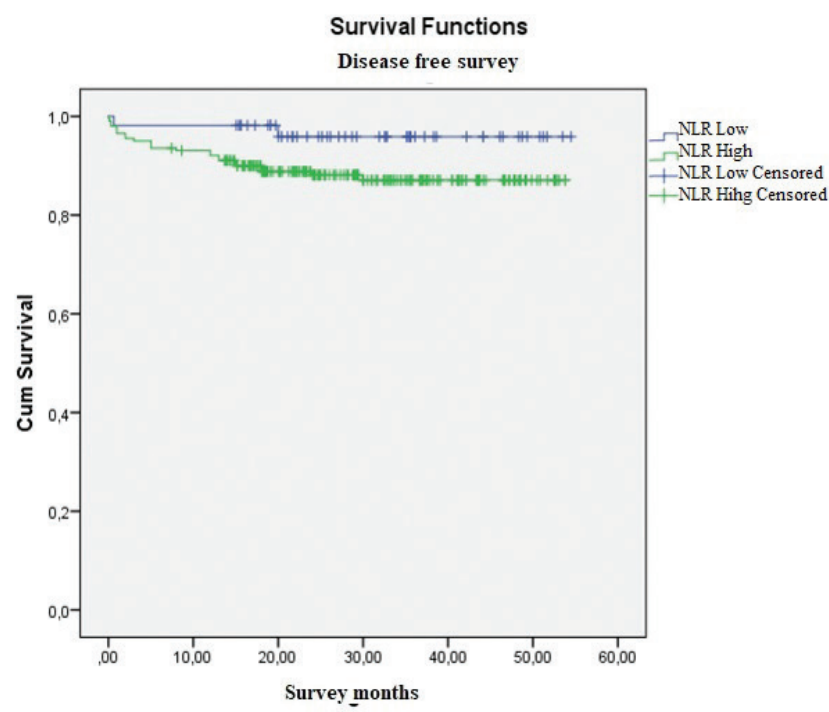

Figure 3. Disease-free survival according to NLR groups NLR: Neutrophil/lymphocyte ratio 
Table 5. Perioperative and postoperative clinical outcomes, oncological outcomes

\begin{tabular}{|c|c|c|c|c|}
\hline \multirow{2}{*}{\multicolumn{2}{|c|}{ Postop hospitalization duration (mean + SD) (min-max) }} & $\begin{array}{l}\text { Low NLR } \\
\mathrm{n}=56\end{array}$ & $\begin{array}{l}\text { High NLR } \\
\mathrm{n}=223\end{array}$ & \multirow{2}{*}{$\begin{array}{l}\mathrm{p}^{*} \\
0.502\end{array}$} \\
\hline & & $\begin{array}{l}10.05+6.69 \\
4.0-40.0\end{array}$ & $\begin{array}{l}9.32+7.34 \\
1.0-75.0\end{array}$ & \\
\hline Postoperative complication* & & $6(10.7)$ & $55(24.7)$ & 0.015 \\
\hline \multirow{2}{*}{ Wound site infection } & Yes & $7(12.5)$ & $32(14.3)$ & \multirow{2}{*}{0.456} \\
\hline & No & $49(87.5)$ & $191(85.7)$ & \\
\hline \multirow{2}{*}{ Intraabdominal abscess } & Yes & $7(12.5)$ & $10(4.5)$ & \multirow{2}{*}{0.034} \\
\hline & No & $49(87.5)$ & $213(95.5)$ & \\
\hline \multirow{2}{*}{ Evisceration } & Yes & $1(1.8)$ & $6(2.7)$ & \multirow{2}{*}{0.574} \\
\hline & No & $55(98.2)$ & $217(97.3)$ & \\
\hline \multirow{2}{*}{ Ileus } & Yes & $2(3.6)$ & $26(11.7)$ & \multirow{2}{*}{0.050} \\
\hline & No & $54(96.4)$ & $197(88.3)$ & \\
\hline \multirow{2}{*}{ Anastomotic leakage } & Yes & $2(3.6)$ & $5(2.2)$ & \multirow{2}{*}{0.426} \\
\hline & No & $54(96.4)$ & $218(97.8)$ & \\
\hline \multirow{2}{*}{ Reoperation } & Yes & $3(5.4)$ & $12(5.4)$ & \multirow{2}{*}{0.647} \\
\hline & No & $53(94.6)$ & $211(94.6)$ & \\
\hline \multirow{2}{*}{ Unplanned hospital readmission } & Yes & $6(10.7)$ & $31(13.9)$ & \multirow{2}{*}{0.352} \\
\hline & No & $50(89.3)$ & $192(86.1)$ & \\
\hline \multirow{2}{*}{ Local recurrence } & Yes & $0(0.0)$ & $11(4.9)$ & \multirow{2}{*}{0.081} \\
\hline & No & $56(100.0)$ & $212(95.1)$ & \\
\hline \multirow{2}{*}{ Distant organ metastasis } & Yes & $1(1.8)$ & $18(8.1)$ & \multirow{2}{*}{0.075} \\
\hline & No & $55(98.2)$ & $205(91.9)$ & \\
\hline
\end{tabular}

*Clavien dindo 3 and above, NLR: Neutrophil/lymphocyte ratio, SD: Standart deviation, min: Minimum, max: Maximum

Table 6. Total survival duration according to NLR groups

\begin{tabular}{|clll|} 
& & $\begin{array}{l}\text { Average }(\text { Mean }+ \text { SD) } \\
\text { (min-max) }\end{array}$ & $\mathrm{p}$ \\
\hline \multirow{3}{*}{ NLR Group } & Low NLR & $52.75+1.22$ & \\
& & $50.361-55.142$ & 0.025 \\
& High NLR & $46.87+1.12$ & \\
& & $44.68-49.07$ &
\end{tabular}

NLR: Neutrophil/lymphocyte ratio, SD: Standard deviation

\section{Discussion}

In recent years, the relationship between inflammation and cancer has started to attract more attention and studies on the relationship between cancer and inflammation have been conducted. It has been shown that there is a significant relationship between systemic inflammation and relatively poor survival in various malignancies. Systemic inflammatory responses are thought to play a role in tumor progression
Table 7. Disease-free survival duration according to NLR groups

\begin{tabular}{|c|c|c|c|}
\hline & & $\begin{array}{l}\text { Average (Mean + } \\
\text { SD) (min-max) }\end{array}$ & $\mathrm{p}$ \\
\hline \multirow{2}{*}{ NLR Group } & Low NLR & $\begin{array}{l}52.73+1.23 \\
50.31-55.15\end{array}$ & \multirow{2}{*}{0.073} \\
\hline & High NLR & $\begin{array}{l}48.13+1.09 \\
45.99-50.27\end{array}$ & \\
\hline
\end{tabular}

by inducing angiogenesis and inhibiting apoptosis and DNA damage, tumor proliferation, and metastasis. ${ }^{3,11,12}$ In addition to the high-risk factors associated with different tumor characteristics, the host's immune system also plays a role in the invasion or metastasis of colon cancer. ${ }^{13}$ The host inflammatory response to cancer cells is also associated with tumor progression. ${ }^{14}$ Inflammation is closely associated with tumorigenesis. Colorectal cancers are infiltrated by various 
immune cells such as neutrophils, T and B lymphocytes, dendritic cells, macrophages, natural killer cells, and mast cells. ${ }^{15,16}$

The meaning of high NLR remains unclear. NLR can potentially be affected by some conditions, especially chronic diseases. ${ }^{17}$ For this reason, these patients were excluded when we were designing our study.

Right colon tumors are considered to be more immunogenic tumors than left colon tumors because of high lymphocyte infiltrations, their association with increased inflammatory response, and high rate of mutation. ${ }^{18}$ In the series of Turker et al., it was reported that there was no statistical difference between right and left colon tumors in terms of NLR value. ${ }^{18}$ Similarly, Choi et al. ${ }^{19}$ reported in their study where the NLR cut off value was 2.6, that there was no correlation between the presence of tumor in the colon or rectum and NLR. In our series, there was no correlation between tumor localization and NLR, in support of the literature.

Kubo $\mathrm{T}$ et al. $^{20}$, in their study where the cutoff for NLR was 2.29 , reported that NLR was associated with poorly differentiated tumors. In contrast, Shen J et al. reported that there was no correlation between histological differentiation and NLR when the cutoff value for NLR was taken as $3 .{ }^{21}$ In our series, poorly differentiated tumors were seen more frequently in patients with an NLR above $2.08(21.5 \%$ vs $8.9 \%, \mathrm{p}=0.031)$.

Several studies have been conducted to identify chemical markers predicting increased postoperative complication risk after colorectal surgery. Procalcitonin and complement C3A levels in the first 24 hours after elective colorectal surgery were found to correlate with the presence of systemic inflammatory response syndrome (SIRS). ${ }^{22}$ In studies investigating the relationship between NLR and postoperative complications, Cook et al. ${ }^{23}$ found a similar NLR value in patients with and without complications, while Caputo et al. ${ }^{24}$ reported in their study including rectum cancer patients who received neoadjuvant treatment, that an NLR over their cutoff value of 3.8 was associated with increased surgical complication rate. In our series, postoperative complications were found to be higher in the high NLR group than in the low NLR group $(24.7 \%$ vs $10.7 \%, \mathrm{p}=0.05)$.

In response to specific chemokines, different immune cell subsets migrate to the tumor microenvironment and regulate tumor immune responses. Direct and indirect interactions in chemokine pathways can reshape the immune and biological phenotypes of a tumor, render the biological behavior unpredictable and alter its metastatic potential. ${ }^{25}$ When the relationship between NLR and recurrence or distant metastasis was examined, no difference was found in the conducted studies. ${ }^{24,26,27}$ In our study, no correlation was found with NLR in terms of local recurrence ( $\mathrm{p}=0.081)$ and distant metastasis $(\mathrm{p}=0.075)$, similar to the literature.

Chiang SF et al. reported that preoperative high NLR $(>3)$ affects disease-free survival in patients with stage I - III CRC. Elevated NLR ( $>3$ ) was associated with a worse outcome (5year disease-free survival $66.3 \%$ vs. $78.9 \%$ in colon cancer, $\mathrm{p}<0.001 ; 60.5 \%$ vs. $66.2 \%$ in rectal cancer, $\mathrm{p}=0.008) .{ }^{23} \mathrm{In}$ our series, the mean survival time was lower in the group with NLR higher than 2.08 compared to the group with NLR lower than 2.08 (44.6 months vs. 50.3 months; $\mathrm{p}=0.025$ ). However, the disease-free survival rate was similar in the two groups. Our study was in support of the literature and elevated NLR was associated with poor survival. ${ }^{17}$

The most important limitation of our study was its retrospective nature, and being a single-center study. However, our patient population was as large as those reported in the literature.

\section{Conclusion}

Various parameters are being investigated to predict the course of CRC disease. We think that NLR, which can be measured easily, is a parameter that can be used to predict the development of postoperative complications and survival. However, further studies are needed.

\section{Ethics}

Ethics Committee Approval: After obtaining permission from the Ethics Committee of Çukurova Faculty of Medicine dated 04.09.2019 and numbered 91/29.

Informed Consent:

Peer-review: Internally and externally peer reviewed.

\section{Authorship Contributions}

Surgical and Medical Practices: O.Y., U.T., A.G.Ü, İ.C.E., A.R., Concept: O.Y., U.T.,

Design: O.Y., U.T., İ.C.E., Data Collection or Processing: U.T., A.G.Ü, Analysis or Interpretation: O.Y., İ.C.E., A.R., Literature Search: O.Y., U.T., A.G.Ü, İ.C.E., A.R., Writing: O.Y., U.T., İ.C.E.

Conflict of Interest: No conflict of interest was declared by the authors.

Financial Disclosure: The authors declared that this study received no financial support.

\section{References}

1. Edwards BK, Ward E, Kohler BA, Eheman C, Zauber AG, Anderson RN, Jemal A, Schymura MJ, Lansdorp-Vogelaar I, Seeff LC, van Ballegooijen M, Goede SL, Ries LA. Annual report to the nation on the status of cancer, 1975-2006, featuring colorectal cancer trends and impact of interventions (risk factors, screening, and treatment) to reduce future rates. Cancer 2010;116:544-573. 
2. Tsai PL, Su WJ, Leung WH, Lai CT, Liu CK. Neutrophil-lymphocyte ratio and CEA level as prognostic and predictive factors in colorectal cancer: A systematic review and meta-analysis. J Cancer Res Ther 2016;12:582-589.

3. Hanahan D, Weinberg RA. Hallmarks of cancer: the next generation. Cell 2011;144:646-674.

4. Roxburgh CS, McMillan DC. Role of systemic inflammatory response in predicting survival in patients with primary operable cancer. Future Oncol 2010;6:149-163.

5. McMillan DC. Systemic inflammation, nutritional status and survival in patients with cancer. Curr Opin Clin Nutr Metab Care 2009;12:223-226.

6. Kwon KA, Kim SH, Oh SY, Lee S, Han JY, Kim KH, Goh RY, Choi HJ, Park KJ, Roh MS, Kim HJ, Kwon HC, Lee JH. Clinical significance of preoperative serum vascular endothelial growth factor, interleukin-6, and C-reactive protein level in colorectal cancer. BMC Cancer 2010;10:203.

7. Maeda K, Shibutani M, Otani H, Nagahara H, Ikeya T, Iseki Y, Tanaka H, Muguruma K, Hirakawa K. Inflammation-based factors and prognosis in patients with colorectal cancer. World J Gastrointest Oncol 2015;7:111117.

8. Walsh SR, Cook EJ, Goulder F, Justin TA, Keeling NJ. Neutrophil lymphocyte ratio as a prognostic factor in colorectal cancer. J Surg Oncol 2005:91:181-184

9. Halazun KJ, Aldoori A, Malik HZ, Al-Mukhtar A, Prasad KR, Toogood GJ, Lodge JP. Elevated preoperative neutrophil to lymphocyte ratio predicts survival following hepatic resection for colorectal liver metastases. Eur J Surg Oncol 2008;34:55-60

10. Wei Y, Zhang X, Wang G, Zhou Y, Luo M, Wang S, Hong C. The impacts of pretreatment circulating eosinophils and basophils on prognosis of stage I-III colorectal cancer. Asia Pac J Clin Oncol 2018;14:e243-e251.

11. Li Z, Zhao R, Cui Y, Zhou Y, Wu X. The dynamic change of neutrophil to lymphocyte ratio can predict clinical outcome in stage I-III colon cancer Sci Rep 2018;8:9453.

12. Mantovani A, Allavena P, Sica A, Balkwill F. Cancer-related infammation, Nature 2008;454:436-444

13. Ueno H, Hawrylowicz CM, Banchereau J. Immunological intervention in human diseases. J Transl Med 2007;5:1-7.

14. Shau HY, Kim A. Suppression of lymphokine-activated killer induction by neutrophils. J Immunol 1988;141:4395-4402.

15. GalonJ, Fridman WH, Pages F. The adaptive immunologicmicroenvironment in colorectal cancer: a novel perspective. Cancer Res 2007:67:1883-1886.

16. Goret NE, Goret CC, Topal U, Ozkan OF. A review of B lymphocytes in tumour immune response. J Stem Cell Res Med 2019;4:1-3.
17. Chiang SF, Hung HY, Tang R, Changchien CR, Chen JS, You YT, Chiang JM, Lin JR. Can neutrophil-to-lymphocyte ratio predict the survival of colorectal cancer patients who have received curative surgery electively? Int J Colorectal Dis 2012;27:1347-1357.

18. Türker S, Karaçin C, İmamoğlu Gİ, Eren T, Esen R, Çılbır E, Altınbas M, Yazılitaş D. The relationship between localization and neutrophil lymphocyte ratio in colon carcinoma. Ortadoğu Tip Dergisi 2018;10:6467.

19. Choi WJ, Cleghorn MC, Jiang H, Jackson TD, Okrainec A, Quereshy FA. Preoperative neutrophil-to-lymphocyte ratio is a better prognostic serum biomarker than platelet-to-lymphocyte ratio in patients undergoing resection for nonmetastatic colorectal cancer. Ann Surg Oncol 2015;22 Suppl 3:S603-613.

20. Kubo T, Ono S, Ueno H, Shinto E, Yamamoto J, Hase K. Impact of the perioperative neutrophil-to-lymphocyte ratio on the long-term survival following an elective resection of colorectal carcinoma. Int J Colorectal Dis 2014;29:1091-1099.

21. Shen J, Zhu Y, Wu W, Zhang L, Ju H, Fan Y, Zhu Y, Luo J, Liu P, Zhou N, Lu K, Zhang N, Li D, Liu L. Prognostic role of Neutrophil-to-Lymphocyte ratio in locally advanced rectal cancer treated with neoadjuvant chemoradiotherapy. Med Sci Monit 2017;23:315-324.

22. Sarbinowski R, Arvidsson S, Tylman M, Oresland T, Bengtsson A. Plasma concentration of procalcitonin and systemic inflammatory response syndrome after colorectal surgery. Acta Anaesthesiol Scand 2005;49:191196.

23. Cook EJ, Walsh SR, Farooq N, Alberts JC, Justin TA, Keeling NJ. Postoperative neutrophil-lymphocyte ratio predicts complications following colorectal surgery. Int J Surg 2007;5:27-30.

24. Caputo D, Caricato M, Coppola A, La Vaccara V, Fiore M, Coppola R. Neutrophil to lymphocyte ratio (NLR) and derived neutrophil to lymphocyte ratio (d-NLR) predict non-responders and postoperative complications in patients undergoing radical surgery after neo-adjuvant radio-chemotherapy for rectal adenocarcinoma. Cancer Invest 2016;34:440-451.

25. Nagarsheth N, Wicha MS, Zou W. Chemokines in the cancer microenvironment and their relevance in cancer immunotherapy. Nat Rev Immunol 2017;17:559-572

26. Dimitriou N, Felekouras E, Karavokyros I, Alexandrou A, Pikoulis E, Griniatsos J. Neutrophils to lymphocytes ratio as a useful prognosticator for stage II colorectal cancer patients. BMC Cancer 2018;18:1202.

27. Ozdemir Y, Akin ML, Sucullu I, Balta AZ, Yucel E. Pretreatment neutrophil/ lymphocyte ratio as a prognostic aid in colorectal cancer. Asian Pac J Cancer Prev 2014;15:2647-2650 